\title{
Comparison of the Fate of Nitrite Added to Whole Meat, Meat Fractions and Model Systems ${ }^{\dagger}$
}

\author{
Misao Emi-Miwa, * Akihiro OKITANI and Masao FuJimaki \\ Department of Agricultural Chemistry, University of Tokyo, Tokyo \\ Received February 23, 1976
}

\begin{abstract}
The fate of nitrite in cured meat was investigated. Of added nitrite-N, $66 \sim 90 \%$ was found as nitrite, nitrate, nitrosothiol, denatured nitrosomyoglobin and gaseous nitrogen compounds, and the remainder of $\mathrm{N}$ was unidentified. The amount of unidentified $\mathrm{N}$ depended on both the curing period and the amount of added sodium ascorbate (AS).

Pork was separated into four fractions: dil. sodium chloride-soluble small-molecular fraction (Fr. 1), dil. sodium chloride-soluble large-molecular fraction (Fr. 2), Weber-Edsall solution-soluble fraction (Fr. 3) and Weber-Edsall solution-insoluble fraction (Fr. 4). Each fraction was cured and the fate of nitrite was examined. In the absence of AS, almost all nitrite- $\mathrm{N}$ was detectable, while in its presence, $73 \sim 82 \%$ of nitrite- $\mathrm{N}$ was detectable in both Fr. 1 and Fr. 2, 78 100\% in Fr. 3 and $94 \sim 100 \%$ in Fr. 4. These results suggest that the unidentified nitrite- $\mathrm{N}$ in cured meat originated mostly from the reaction between the three meat fractions (Frs. 1, 2 and 3), nitrite and AS.
\end{abstract}

Since nitrite has been confirmed to be a precursor of strong carcinogenic nitrosamines, the wholesomeness of nitrite as a curing agent has aroused great concern. In spite of many studies, our knowledge of the fate of nitrite in cooked cured meat is still not enough to solve this problem. Quantitative investigations of the fate of nitrite are now necessary.

Our recent work ${ }^{1)}$ on the fate of nitrite in meat-curing model systems composed of myoglobin, nitrite and ascorbate showed that the added nitrite was almost completely recovered in the form of the following four compounds: nitrite, nitrate, DNOMb* and gaseous nitrogen compounds. The present paper describes the fate of the nitrite in whole meat and its four fractions i.e., dil. $\mathrm{NaCl}-$ soluble small-molecular fraction (Fr. 1), dil. $\mathrm{NaCl}$-soluble large-molecular fraction (Fr. 2), Weber-Edsall solution ${ }^{2}$-soluble fraction (Fr. 3) and Weber-Edsall solution-insoluble fraction (Fr. 4).

Mirna et al ${ }^{3)}$ have reported that meat con-

$\dagger$ Fate of Nitrite Added to Cured Meat. Part II. Jee Reference 1).

* Abbreviations used in this paper: DNOMb, Jenatured nitrosomyoglobin; AS, sodium ascorbate; AM-buffer, ammonia-ammonium acetate buffer; $\mathrm{Mb}$, nyoglobin. tains $20 \mathrm{~mm}$ sulfhydryl group which can react with nitrite to give nitrosothiol. Saville) has shown that heavy metals split nitrosothiol into nitrite and sulfhydryl. Mirna et al. ${ }^{3,5)}$ and Olsman et al ${ }^{6}{ }^{6}$ have used this reaction to determine nitrosothiols, revealing that the sulfhydryl group can play a very important role in influencing the fate of nitrite. In a study on the specific interaction bewteen nitrite and sulfhydryl groups of myosin, Kubber $\phi \mathrm{d}$ et $a l^{7}{ }^{7}$ have shown that twenty percent of the total nitrite lost was changed to nitrosothiol-N under the following conditions: molar ratio of $\mathrm{SH} /$ nitrite, $1 / 1 ; \mathrm{pH}, 5.0$; temperature, $100^{\circ} \mathrm{C}$; and reaction time, $1 \mathrm{hr}$.

In the present work, determination was conducted on nitrosothiol as well as on nitrite, nitrate, $\mathrm{DNOMb}$ and gaseous nitrogen compounds originating from nitrite in cooked cured meat.

\section{MATERIALS AND METHODS}

Fractionation of meat. Minced meat (commercial pork) was homogenized very mildly by hand with an equal weight of $0.05 \mathrm{M} \mathrm{NaCl}$ for 15 min and centrifuged at $11,000 \times g$ for $15 \mathrm{~min}$. The supernatant obtained was dialyzed against $0.05 \mathrm{M} \mathrm{NaCl}$ and the diffusate was concentrated with a rotary evaporator at 
$30^{\circ} \mathrm{C}$. The concentrate was used as Fr. 1 , and the dialysate as Fr. 2 . The residue was homogenized very mildly with a 6-fold volume of Weber-Edsall solution $\left(0.6 \mathrm{M} \mathrm{KCl}, 0.04 \mathrm{M} \mathrm{NaHCO}_{3}\right.$ and $0.01 \mathrm{M} \mathrm{Na}_{2} \mathrm{CO}_{3}$ ) for $10 \mathrm{~min}$. After standing for $24 \mathrm{hr}$ at $4^{\circ} \mathrm{C}$, the mixture was centrifuged at $7300 \times g$ for $15 \mathrm{~min}$. The supernatant was used as Fr. 3, and residue as Fr. 4.

Composition of reaction mixture. Reaction mixtures contained minced whole meat or one of its fractions, $1 \mathrm{~mm}{ }^{18} \mathrm{~N}$-sodium nitrite $(99.0$ atom $\%$, from Hikari Kogyo Co., Ltd.), 0 or 20 mm AS, $2 \% \mathrm{NaCl}$ and $0.08 \mathrm{M}$ acetate buffer ( $\mathrm{pH} 5.5$ ). The formulation was made according to Tables $I$ and III. Twenty $g$ of the reaction mixture contained $17.6 \mathrm{~g}$ of whole meat. The protein concentrations of Fr. 2 and Fr. 3 in the reaction mixtures were 5 and $10 \mathrm{mg} / \mathrm{ml}$, respectively. Fr. 1 was concentrated to the same volume as that of Fr. 2, whereas Fr. 4 was diluted with a three-fold volume of water.

Curing and cooking. Twenty $\mathrm{ml}(20 \mathrm{~g}$ in the case of whole meat) of the reaction mixture was placed in a tightly sealed flask and allowed to cure at $4^{\circ} \mathrm{C}$ for 0,3 or 7 days. The mixture was then cooked at $70^{\circ} \mathrm{C}$ for $60 \mathrm{~min}$ and the amounts of DNOMb, nitrite, nitrate, nitrosothiol and gaseous nitrogen compounds were determined.

DNOMb determination. The method was the same as described in the previous paper. ${ }^{13}$

Nitrite, nitrate and nitrosothiol determination. Two $\mathrm{ml}$ ( $2 \mathrm{~g}$ in the case of whole meat) of the reaction mixture and about $80 \mathrm{ml}$ of $0.1 \mathrm{M}$ AM-buffer solution $(\mathrm{pH} \mathrm{9.0)}$ were placed in a $100 \mathrm{ml}$ llask and heated at $80^{\circ} \mathrm{C}$. After $10 \mathrm{~min}, 2 \mathrm{ml}$ of a zinc uranyl acetate solution, prepared by mixing $100 \mathrm{ml}$ of $0.1 \mathrm{M}$ zinc acetate with $10 \mathrm{~g}$ of uranyl acetate in $100 \mathrm{ml}$ ammonium acetate, was added and heating was contained for another $5 \mathrm{~min}$. After cooling the contents rapidly to room temperature, the volume was made up to $100 \mathrm{ml}$ with AM-buffer solution and filtered through a Toyo No. 5C filter paper. The filtrate was used as a test solution.

a) Nitrite and nitrate determination. The same method as described in the previous paper. ${ }^{1)}$

b) Nitrosothiol determination. Nitrosothiol was. determined according to Saville's method, ${ }^{4)}$ using twoml of saturated mercuric chloride solution instead of zinc uranyl acetate. The amount of nitrosothiol- $\mathrm{N}$ was obtained by subtracting the amount of nitrite detected in the absence of mercuric chloride from that in the presence of mercuric chloride.

Gaseous nitrogen compounds determination. The method was the same as described in the previous paper. ${ }^{13}$

\section{RESULTS}

\section{Fate of nitrite in whole meat}

Table I shows the fate of nitrite added to whole meat cured with and without AS. In the absence of AS, $77 \%$ of added nitrite was recovered from the whole meat on 0-day curing and $46.5 \%$ on 7 -day curing, while almost all of the nitrite was recoyered in $\mathrm{Mb}$-nitrite model system as shown in Table II. Therefore it is clear that nitrite added to whole meat decomposed both during the curing and at the cooking stage. These results suggest that compounds having the same effect as AS are present in meat.

In the presence of $\mathrm{AS}$, the amount of nitrite detected on both 0 - and 7-day curing was

Table I. Fate of Nitrite in Whole Meat

Minced meat $(17.6 \mathrm{~g}$ ) homogenized with $1 \mathrm{ml}$ of $0.02 \mathrm{M}$ sodium nitrite, $1 \mathrm{ml}$ of $0,0.04$ or $0.4 \mathrm{M}$ AS and $0.4 \mathrm{~g}$ of $\mathrm{NaCl}$ was cooked at $70^{\circ} \mathrm{C}$ for $60 \mathrm{~min}$ after curing for 0 and 7 days.

\begin{tabular}{cccccccc}
\hline \multicolumn{2}{c}{ Conditions } & \multicolumn{7}{c}{ Fate of nitrite } \\
\cline { 5 - 8 } $\begin{array}{c}\text { Curing period } \\
\text { (days) }\end{array}$ & $\begin{array}{c}\left.\mathrm{AS}^{b}\right) \\
(\mathrm{mM})\end{array}$ & DNOMb-N & $\begin{array}{c}\text { Nitroso- } \\
\text { thiol-N }\end{array}$ & $\begin{array}{c}\text { Nitrite } \\
-\mathrm{N}\end{array}$ & $\begin{array}{c}\text { Nitrate } \\
-\mathrm{N}\end{array}$ & $\begin{array}{c}\text { Gaseous } \\
-\mathrm{N}\end{array}$ & Total-N \\
\hline \multirow{2}{*}{0} & 0 & 1.8 & 0.9 & 77.0 & 10.0 & 0 & 89.7 \\
& 2 & 4.9 & 2.5 & 56.0 & 19.7 & 2.3 & 85.4 \\
\hline & 20 & 6.2 & 7.1 & 30.0 & 22.7 & 4.5 & 70.5 \\
\hline
\end{tabular}

a) Expressed as $\mathrm{N}$ atom $\%$ added nitrite- $\mathrm{N}$

b) Final concentration 
Table II. Fate of Nitrite in Mb-Nitrite Model Systems

The model systems composed of $5 \mathrm{ml}$ of $1 \mathrm{~mm}$ sperm whale $\mathrm{Mb}, 5 \mathrm{ml}$ of $5 \mathrm{mM}$ sodium nitrite, $10 \mathrm{ml}$ of $0.2 \mathrm{~m}$ acetate buffer ( $\mathrm{pH} 5.5$ ) and $5 \mathrm{ml}$ of water were cooked at $70^{\circ} \mathrm{C}$ for $60 \mathrm{~min}$ after curing for 0 and 7 days.

\begin{tabular}{cccccc}
\hline \multirow{2}{*}{$\begin{array}{c}\text { Curing period } \\
\text { (days) }\end{array}$} & DNOMb-N & Nitrite-N & Nitrate-N & Gaseous-N & Total-N \\
\cline { 2 - 5 } & 0 & 100.0 & 0 & trace & 100.0 \\
7 & 0 & 96.2 & 3.4 & 1.0 & 100.6 \\
\hline
\end{tabular}

a) Expressed as $\mathrm{N}$ atom $\%$ of added nitrite- $\mathrm{N}$.

less than that in the absence of AS (Table I). In our previous work ${ }^{1)}$ on $\mathrm{Mb}$-nitrite-AS model system, the amount of nitrite detected was $63 \%$ on 0 -day curing with $2 \mathrm{~mm} \mathrm{AS,} 41 \%$ on 0 -day curing with $20 \mathrm{~mm} \mathrm{AS}$, and $19 \%$ and $2.4 \%$ on 7 -day curing with respectively $2 \mathrm{~mm}$ and $20 \mathrm{~mm}$ AS. This model system did not contain $\mathrm{NaCl}$, whereas the system used in the present study contains $2 \% \mathrm{NaCl}$. Even if the effect of the $\mathrm{NaCl}$ addition is taken into account, the present results (Table I) are comparable to those obtained from the model system. These results suggest that the compound in meat decomposes nitrite as well as AS does. However, the nitrite decomposition reaction by $\mathrm{AS}$ and that by the compound were not synergistic.

It was noteworthy that in the case of whole

Table III. Fate of Nitrite in Each of Four Meat Fractions

The reaction mixtures composed of $17 \mathrm{ml}$ of each meat fraction, $1 \mathrm{ml}$ of $0.02 \mathrm{M}$ sodium nitrite, $1 \mathrm{ml}$ of 0 or $0.4 \mathrm{M} \mathrm{AS}, 0.4 \mathrm{~g}$ of $\mathrm{NaCl}$ and $1 \mathrm{ml}$ of $1.6 \mathrm{M}$ acetate buffer $\left(\mathrm{pH} \mathrm{5.5)}\right.$ were cooked at $70^{\circ} \mathrm{C}$ for $60 \mathrm{~min}$ after curing for 0,3 and 7 days respectively.

\begin{tabular}{|c|c|c|c|c|c|c|c|c|}
\hline \multicolumn{3}{|c|}{ Conditions } & \multicolumn{5}{|c|}{ Fate of nitrite ${ }^{a}$} & \multirow[b]{2}{*}{ Total-N } \\
\hline $\begin{array}{l}\mathrm{AS}^{b ?} \\
(\mathrm{mM})\end{array}$ & $\begin{array}{l}\text { Curing } \\
\text { period } \\
\text { (days) }\end{array}$ & Fraction & DNOMb-N & $\begin{array}{l}\text { Nitroso- } \\
\text { thiol-N }\end{array}$ & $\begin{array}{c}\text { Nitrite } \\
-N\end{array}$ & $\begin{array}{c}\text { Nitrate } \\
-N\end{array}$ & $\begin{array}{c}\text { Gaseous } \\
-\mathrm{N}\end{array}$ & \\
\hline \multirow{8}{*}{0} & \multirow{4}{*}{0} & 1 & 0 & 0.9 & 90.0 & 3.8 & 0 & 94.7 \\
\hline & & 2 & 0 & 0 & 92.5 & 8.1 & 1.0 & 101.6 \\
\hline & & 3 & 0 & 1.3 & 101.9 & 2.9 & trace & 106.1 \\
\hline & & 4 & 0 & 0 & 97.4 & 3.0 & 0.9 & 100.4 \\
\hline & \multirow{4}{*}{7} & 1 & 0 & 0 & 93.5 & 7.1 & 1.7 & 102.3 \\
\hline & & 2 & 0 & 1.2 & 87.6 & 11.2 & 1.0 & 101.0 \\
\hline & & 3 & 0 & 1.0 & 96.9 & 6.5 & 0 & 104.4 \\
\hline & & 4 & 0 & 0 & 99.3 & 4.9 & trace & 104.2 \\
\hline \multirow{8}{*}{20} & \multirow{4}{*}{0} & 1 & 0 & 0 & 54.5 & 8.3 & 10.8 & 73.6 \\
\hline & & 2 & 0.5 & 1.8 & 51.4 & 19.1 & 8.0 & 80.8 \\
\hline & & 3 & 0 & 4.1 & 79.2 & 11.3 & 5.5 & 100.1 \\
\hline & & 4 & 0 & 0.4 & 82.7 & 16.4 & 0 & 99.5 \\
\hline & \multirow{4}{*}{3} & 1 & 0 & 0.6 & 38.0 & 20.8 & 14.1 & 73.5 \\
\hline & & 2 & 0.6 & 5.2 & 43.9 & 19.0 & 4.2 & 73.2 \\
\hline & & 3 & 0 & 4.1 & 55.1 & 14.6 & 6.8 & 80.6 \\
\hline & & 4 & 0 & 5.5 & 86.3 & 12.2 & trace & 104.0 \\
\hline & \multirow{4}{*}{7} & 1 & 0 & 1.8 & 26.3 & 32.0 & 13.1 & 73.2 \\
\hline & & 2 & 0.5 & 3.0 & 42.7 & 31.4 & 4.0 & 81.6 \\
\hline & & 3 & 0 & 0.8 & 46.4 & 23.3 & 7.8 & 78.3 \\
\hline & & 4 & 0 & 2.6 & 78.7 & 10.2 & 2.9 & 94.4 \\
\hline
\end{tabular}

a) Expressed as $\mathrm{N}$ atom $\%$ of added nitrite- $\mathrm{N}$.

b) Final concentration. 
meat the recovery of nitrite- $\mathrm{N}$ was $66 \sim 90 \%$ and a remarkable amount of added nitrite remained unidentified, though the recovery was $100 \%$ in the model system of our previous work. On 0-day curing, the unidentified nitrite- $\mathrm{N}$ increased as AS increased, but decreased in the case of 7-day curing. Unidentified nitrite- $\mathrm{N}$ was detected even if AS had not been added, and increased with the curing period; this finding is different from that of meat fraction (Table III). These results show that some components other than $\mathrm{Mb}$ and/or AS were involved in the formation of unidentified- $\mathrm{N}$ compound.

\section{Fate of nitrite in various meat fractions}

In order to determine the components of meat which may contribute to the differences between the fate of nitrite in whole meat and the fate in $\mathrm{Mb}$-AS model system, four fractions extracted from meat were cured with nitrite, and nitrite- $\mathrm{N}$ containing substances, nitrite, nitrate, $\mathrm{DNOMb}$, nitrosothiol and gaseous compounds, were determined as shown in Table III.

\section{Fate of nitrite in Fr. I}

When Fr. 1 was cured without AS, the added nitrite was almost completely recovered as nitrite- $\mathrm{N}$ on 7-day as well as on 0 -day curing, recoveries being 102 and $95 \%$, respectively.

In the presence of AS, nitrite decreased remarkably with the formation of a notable amount of gas. With increase on the curing period, nitrite- $\mathrm{N}$ decreased and both nitro- sothiol and nitrate- $\mathrm{N}$ increased, while gaseous$\mathrm{N}$ remained constant at a level of $11 \sim 14 \%$. It was notable that the production of gaseous$\mathrm{N}$ was larger in this fraction than the other meat fractions. The decomposition rate of nitrite in this fraction was larger than that of AS-nitrite model system in both 0 - and 7-day cured samples (Table IV). This suggests that Fr. 1 causes nitrite breakdown in the presence of $\mathrm{AS}$, both during the curing. period and at the cooking stage.

The recovery of the added nitrite was about $73 \%$ after any of the three curing periods. In other words, $27 \%$ of nitrite changed into unidentified compounds. This reaction seems to be unaffected by curing period.

\section{Fate of nitrite in Fr. 2}

The effect of Fr. 2 on the fate of nitrite in the absence of AS was very similar to that of Fr. 1. About $90 \%$ of added nitrite- $\mathrm{N}$ was detected as nitrite and its recovery was $100 \%$.

In the presence of $\mathrm{AS}$, almost all $\mathrm{Mb}$ in this fraction was covered to DNOMb with generation of gas in each case. On 0-day curing nitrite decreased remarkably at the same rate as in Fr. 1. However, the decrease during 7-days curing was smaller in Fr. 2 than in Fr. 1, and was comparable to that observed in AS-nitrite model system (Table IV). This suggests that Fr. 2 provokes nitrite breakdown at the cooking stage, but not during the curing.

The recovery of the added nitrite lay between 73 and $82 \%$ in Fr. 2. The uniden-

Table IV. Fate of Nitrite in Nitrite-AS Model System

The model systems composed of $5 \mathrm{ml}$ of $5 \mathrm{~mm}$ sodium nitrite, $5 \mathrm{ml}$ of 10 or $100 \mathrm{mM} \mathrm{AS}, 10 \mathrm{ml}$ of $0.2 \mathrm{M}$ acetate buffer (pH 5.5) and $5 \mathrm{ml}$ of water were cooked at $70^{\circ} \mathrm{C}$ for $60 \mathrm{~min}$ after curing for 0 and 7 days.

\begin{tabular}{|c|c|c|c|c|c|}
\hline \multicolumn{2}{|c|}{ Conditions } & \multicolumn{4}{|c|}{ Fate of nitrite $\left.{ }^{a}\right)$} \\
\hline $\begin{array}{l}\left.\mathrm{AS}^{b}\right) \\
(\mathrm{mM})\end{array}$ & $\begin{array}{l}\text { Curing period } \\
\text { (days) }\end{array}$ & Nitrite-N & Nitrate-N & Gaseous-N & Total-N \\
\hline \multirow[t]{3}{*}{2} & 0 & 89.0 & 8.0 & 2.2 & 99.2 \\
\hline & 7 & 78.4 & 24.0 & 0 & 102.4 \\
\hline & 0 & 76.0 & 15.2 & 4.8 & 96.0 \\
\hline 20 & 7 & 64.4 & 22.4 & 5.4 & 92.2 \\
\hline
\end{tabular}

a) Expressed as $\mathrm{N}$ atom $\%$ of added nitrite- $\mathrm{N}$.

b) Final concentration. 
tified nitrite- $\mathrm{N}$ comprised $20 \%$ of the added nitrite- $\mathrm{N}$ in the case of 0 -day curing (Table III). In the 3-day cured sample the unidentified nitrite- $\mathrm{N}$ level increased to $27 \%$, whereas in the 7-day cured sample it was almost equal to the original level $(20 \%)$.

Recently Knowles et al. ${ }^{81}$ investigated the interaction of nitrite with bovine serum albumin at gastric $\mathrm{pH}$ and obtained 3-nitrotyrosine, dopa and 6-hydroxynorleucine. In the present work the interaction of nitrite with proteins in Fr. 2 was also investigated. However, acid analysis of such nitrite-treated proteins showed no significant changes.

\section{Fate of nitrite in Fr. 3}

In the absence of AS, nitrite hardly changed and the amount of nitrosothiol was very small, although this fraction contained a large amount of sulfhydryl groups and the molar ratio of nitrite to $\mathrm{SH}$ was estimated to be approximately $1: 2,{ }^{7}$ ) on the assumption that only myofibrilar proteins constituted this fraction.

In the presence of $\mathrm{AS}$, only about $4 \%$ of the added nitrite was determined as nitrosothiol-N on 0 - as well as 3 -day curing. The percentage of nitrosothiol- $\mathrm{N}$ in the total loss of nitrite- $\mathrm{N}$ was calculated as 20,9 and $1.5 \%$ on 0-, 3-and 7-day curing, respectively. These results were similar to the observation of Kubber $\phi \mathrm{d}$ et al. ${ }^{\text {i }}$

In contrast to the case of Fr. 2, the amount of nitrite was large on 0-day curing, and decreased remarkably in the 3- or 7-day cured samples. This finding indicates that Fr. 3 produces the breakdown of nitrite at the cooking stage and also during the curing.

It was also noteworthy that in the 0-day cured sample all the added nitrite was recovered in Fr. 3 and in the 3- and 7-day cured samples the recovery was reduced to 81 and $78 \%$, respectively. The values of nitrosothiol, nitrite and gaseous- $\mathrm{N}$ were almost similar for 0 - and 3-day curing, and the decrease i.e., $24.1 \%$ of the added nitrite- $\mathrm{N}$ from 0 -day to 3 -day curing was equal to the increase in unidentified nitrite- $\mathrm{N}$ during these 3 days.
These results suggests that changes in contractile proteins during the curing accelerated the nitrite breakdown and produced unidentified compounds.

\section{Fate of nitrite in Fr. 4}

In the absence of AS, the added nitrite hardly changed. In the presence of AS, nitrite decreased at a rate similar to that in the nitrite-AS model system (Table IV). The recovery of the added nitrite was almost $100 \%$ under the conditions shown in Table IV, even when AS was present. These results led to the conclusion that Fr. 4 hardly affects the decomposition of added nitrite.

\section{DISCUSSION}

The present work indicates that the fate of nitrite in whole meat is different from that in the Mb-nitrite (Table II) and the $\mathrm{Mb}$ nitrite-AS model system (our previous paper ${ }^{1 '}$ ) in the following points.

a) In whole meat there are components that can decompose nitrite without AS, both during the curing and at the cooking stage.

b) Unidentified nitrite- $\mathrm{N}$ is produced by curing as well as by cooking, and its production can be observed even without AS. However, AS can increase its amount.

c) A significant amount of nitrite- $N$ changed into gaseous products even on 7-day curing.

These findings on the fate of nitrite in the meat fraction-nitrite-AS system contribute to the understanding of the components in meat which are responsible for the above-mentioned differences.

Concerning the first point, it is estimated that it was observed that when cured without AS none of the meat fractions decomposes nitrite as does whole meat. This difference in nitrite decomposition between the individual meat fractions and whole meat can be attributed either to a loss in the activity of the effective component during the preparation of the meat fractions or to the decomposition of nitrite resulting from the cooperative reaction 
of some of the fractions.

In the presence of AS, nitrite detected decreased greatly in both Fr. 1 and Fr. 2 on 0 -day curing. The amount of nitrite detected was more than expected when nitrite was decomposed only by AS (see Table IV). This finding shows that there is a cooperative reaction between $\mathrm{AS}$ and some components of meat fractions. By comparing the decomposition rate of nitrite in the nitrite-AS system with that in the nitrite-Mb-AS system, it becomes clear that Mb in Fr. 2 is one of these components. However, possible components other than $\mathrm{Mb}$ are still unknown.

On the second point, it is probable that in the presence of AS a notable amount of unidentified nitrite- $\mathrm{N}$ is produced on 0-day curing in both Fr. 1 and Fr. 2, but not in Fr. 3 or in Fr, 4. On 7-day curing, the amount of unidentified nitrite- $\mathrm{N}$ in Fr. 1 and in Fr. 2 was unchanged, but increased greatly in Fr. 3. These results suggest that in the presence of AS, Fr. 1 and Fr. 2 are involved in the production of unidentified nitrite- $\mathrm{N}$ on 0 - and 7-day curing, whereas Fr. 3 is concerned with that on 7-day curing.

In the absence of AS, the amount of unidentified nitrite- $\mathrm{N}$ in whole meat reached $10 \%$ on 0 -day and $31.5 \%$ on 7 -day curing. However, the results with meat fraction-nitrite system showed that significant amounts of unidentified nitrite- $\mathrm{N}$ were not produced by the individual fractions. The reason for this difference appears to be the same as that responsible for the difference between the rate of nitrite decomposition in the whole meat and that in any of the meat fractions without AS. As far as the third point is concerned,
Frs. 2, 3 and in particular Fr. 1 may be concerned with the gas production.

Besides these three points it is interesting that nitrosothiol can be produced by the reaction of added nitrite with every meat fraction, especially with Fr. 4. It should also be noted that Fr. 4 has only a little, if any, effect on the decomposition of the nitrite.

Since unidentified nitrite- $\mathrm{N}$ detected in whole meat is very important to asses the safety of nitrite, the true chemical nature of unidentified nitrite- $\mathrm{N}$ should be completely elucidated. The results shown in Table III suggest that a detailed investigation on the products of the reaction between the three meat fractions (Frs. 1, 2 and 3) and nitrite to a certain extent may resolve the controversial aspects of the safety of nitrite curing.

Acknowledgement. The authors wish to thank Prof. K. Kumazawa and his associates of the University of Tokyo for helpful advice on the optical nitrogen15 analysis.

\section{REFERENCES}

1) M. Fujimaki, M. Emi and A. Okitani, Agr. Biol. Chem., 39, 371 (1975).

2) A. Szent-Gyorgyi, "Chemistry of Muscular Contraction," Academic Press Inc., New York, 1951.

3) A. Mirna und K. Hofmann, Fleischwirtschaft, 10, 1361 (1969).

4) B. Saville, Analyst, 83, 670 (1958).

5) A. Mirna, Proceedings of 16 th European Meeting of Meat Research Workers, Varna, Bulgaria, 1970, p. 681 .

6) W. J. Olsman and B. Krol, Proceedings of 18th Meeting of Meat Research Workers, Guelph, Canada, 1972, p. 409.

7) G. Kubber $\phi$ d, R. G. Cassens and M. L. Creaser, J. Food Sci., 39, 1228 (1974).

8) M.E. Knowles, D.J. McWeeny, L. Couchman and M. Thorogood, Nature, 247, 288 (1974). 